\title{
CHANGE IN THE PARAMETERS OF SOILS CONTAMINATED BY OIL AND OIL PRODUCTS
}

\author{
ZAFARJON JABBAROV ${ }^{1 *}$, TOKHTASIN ABDRAKHMANOV ${ }^{1}$, ALIM PULATOV $^{2}$, \\ PETER KOVÁČIK ${ }^{3}$, KHABIBULLO PIRMATOV ${ }^{2}$
}

\author{
${ }^{1}$ National University of Uzbekistan named after Mirzo Ulugbek, Tashkent, Uzbekistan \\ ${ }^{2}$ EcoGIS Center, Tashkent Institute of Irrigation and Agricultural Mechanization Engineers, Tashkent, Uzbekistan \\ ${ }^{3}$ Slovak University of Agriculture in Nitra, Slovak Republic
}

JABBAROV, Z. - ABDRAKHMANOV, T. - PUlATOV, A. - KOVÁČIK, P. - PIRMATOV, K.: Change in the parameters of soils contaminated by oil and oil products. Agriculture (Polnohospodárstvo), vol. 65, 2019, no. 3, pp. $88-98$.

The oil well drilling and oil processing industries are globally the main contaminants of environmental condition caused by human economic activities. Oil spills have a negative impact on the environment, economy, and society. In this research, the effects of oil with different chemical contents on soil types formed in two soil-climatic conditions have been studied. The purpose of this research is to study the change of soil properties by oil pollution. The experiments have been conducted in irrigated and non-irrigated soils of the desert region of the Kashkadarya and Surkhandarya (Uzbekistan). The results have shown that aggregates $(0.25 ; 0.5 ; 1 ; 2 ; 3 ; 5 ; 7 ; 10 \mathrm{~mm})$ which are the important of soil fertility have changed by oil and oil production, and the changes have proven to be temporary. The effect of the $5 \%$ and $15 \%$ concentrations of oil, engine oil, petrol, kerosene has been studied. The aggregates $0.25 \mathrm{~mm}$ and $0.5 \mathrm{~mm}$ have the biggest change among aggregates, in fact, aggregates of $0.25 \mathrm{~mm}$ at the level of $5 \%$ of oil decreased by $27.02 \%$, at the level of $15 \%$ of oil decreased by $99.8 \%$, at the level of $5 \%$ of kerosene decreased by $2 \%$, at the level of $15 \%$ of oil decreased by $98.1 \%$. Aggregates of $0.5 \mathrm{~mm}$ at the level of $5 \%$ of oil decreased by $6.44 \%$, at the level of $15 \%$ of oil decreased by $67.14 \%$, at the level of $5 \%$ of kerosene decreased by $12.75 \%$, at the level of $15 \%$ of oil decreased by $92.8 \%$. Engine oil and Petrol at levels 5 and 15 have relatively rare changed. Also, as a result of oil and oil pollution, the total carbon dioxide in the soil has grown briefly, which is an anthropogenic carbon and insignificant for soil fertility and humus. As a result, an anthropogenic carbon increased in gray-brown soil (Durisols Technic, WRB) at $0-35 \mathrm{~cm}$ layer by $0.22 \%$, irrigated meadow-alluvial soil (Fluvisols, WRB) by $0.31 \%$, irrigated gray-brown soil (Durisols Technic, WRB) by $0.44 \%$, irrigated Takyr-meadow soil (Calsisols, WRB) by $0.25 \%$, Takyr soil (Calsisols, WRB) by $0.32 \%$, sandy Desert soil (Durisols Technic, WRB) by $0.21 \%$.

Key words: soil, oil, pollution, aggregate, humus, organic carbon, bioremediation

Oil well drilling and oil processing industries are the main contaminants of environmental condition. According to Karpov (2013), two billion tons of oil drills over the world annually, only 45-50 million tons (about $2 \%$ ) contaminates the environment. Soil pollution is a global problem in both developed and developing countries (Errington et al. 2018).
Contamination with total petroleum hydrocarbons (TPH) subsequent to refining activities is currently one of the major environmental problems (Guarino et al. 2017). Oil spills have a negative impact on the environment, economy, and society (Lim et al. 2016). The environmental problems of oil fields are caused by human economic activities, including the

Zafarjon Jabbarov (*Corresponding author), National University of Uzbekistan named after Mirzo Ulugbek, Department of Soil science and Agrochemistry, Faculty of Biology, 100174, Tashkent, Uzbekistan. E-mail: zafarjonjabbarov@gmail.com 
development of the oil and gas refining industry and hydrocarbon feedstock processing (Tumanyan et al. 2017). Contamination with total petroleum hydrocarbons (TPH) subsequent to refining activities is currently one of the major environmental problems (Guarino et al. 2017). Bioremediation is a promising technique for the reclamation of oil-polluted soils (Soleimani et al. 2013). The consumption of hydrocarbons in the world is steadily growing with the response to the progress of civilization. It is accompanied by the continuous flow of hydrocarbon pollutants into the environment (Panchenko et al. 2017). Pollution caused by petroleum and its derivatives are the most important problems in the environment (Iqbal et al. 2016).

Oil hydrocarbons affect on soil mineral, organic and chemical contents, physical and biological properties, plants as well as $\mathrm{pH}$ change, carbonate amounts and increasing salt content in the soil that are visible (Cruz et al. 2013; Petrova et al. 2014). Adding crude oil to the soil reduced its permeability. It was connected with the entrapment of the crude oil within the pore spaces of the soil (Akinwumi et al. 2014). Total petroleum hydrocarbon is the major constituent in unrefined petroleum oil that has a severe adverse effect on soil properties, qualities, and biota (Akpoveta 2016). Hydrocarbons are the main components of diesel oil and they are toxic for the majority of plants (Balliana et al. 2017). Lawson et al. (2012) studied the change of nutrients and carbon content in the soil. For example, in the soil polluted with $10 \mathrm{~g} / \mathrm{kg}$ dose of diesel fuel, the bacteria available nutrients such as carbon, nitrogen, and phosphorus have decreased within 15-40 days. Crude oil contamination significantly increases the soil $\mathrm{pH}$ up to 8.0 and reduces available phosphorus concentrations in the soil (Wang et al. 2013).

The bioremediation of crude oil contaminated soil is an effective process to clean petroleum contaminant from the environment (Roy et al. 2014). Bioremediation is an economically and environmentally-friendly procedure based on the metabolic capacities of microorganisms to degrade contaminants biochemically (Huang et al. 2013; Kästner et al. 2016). Bioaugmentation is a promising technology to clean up sites contaminated by the petrochemical industry (Gargouri et al. 2014). Biological remediation technologies are an environmentally friendly approach for the treatment of polluted soils (Agnello et al. 2016). The moderate concentrations of crude oil activate the oil-degrading microorganisms, which promote in turn the efficiency of bioremediation (Moubasher et al. 2015). Therefore, the investigation of oil chemical impacts on individual soil is essential.

In this research, the effects of oil with different chemical contents on soil types formed in two soil-climatic conditions have been studied.

The purpose of the research is to study the change of soil properties by oil pollution. Defining the recultivation measures based on soil properties.

\section{MATERIAL AND METHODS}

The experiments have been conducted in irrigated and non-irrigated soils of the desert region of the Kashkadarya (lat. $38^{\circ}$; lon. $66^{\circ}$ ) and Surkhandarya (lat. $38^{\circ}$; lon. $67^{\circ}$ ) located in the southern regions of the Republic of Uzbekistan.

The climate of Kashkadarya is formed as a result of the interconnection of climatic processes in the desert located in the west and the mountainous region in the east. The annual rainfall in 2011-2016 in the study area was $57.5-104.2 \mathrm{~mm}$, the absolute maximum of the air temperature in July was $46.8^{\circ} \mathrm{C}$, the absolute minimum of the air temperature in January was $-6.3^{\circ} \mathrm{C}$. The average wind speed was about $1.5 \mathrm{~m} / \mathrm{s}$

Surkhandarya region is a sunny region with an inherent dry subtropical climate of the republic. Its climate is characterized by warm winter and hot, dry and long summer. The strong wind, blowing at a speed of $2.9-3.1 \mathrm{~m} / \mathrm{s}$ brings a lot of dust. The amount of precipitation in 2016 was $110-149.3 \mathrm{~mm}$, the absolute maximum of the air temperature in July was $+44.4-44.6^{\circ} \mathrm{C}$, the absolute minimum of the air temperature in January was $-5.3^{\circ} \mathrm{C}$, the absolute maximum of the air temperature in January was $+16.8^{\circ} \mathrm{C}$.

Soil samples were taken following distances 0.8 , $2,6,10,14,18,20,22 \mathrm{~km}$ layers from oil mine and oil-gas industry. Soil samples were air-dried and saved in $\pm 11^{\circ} \mathrm{C}$ until laboratory analyses. The following soils were selected: I-point - gray-brown soils (Durisols Technic, WRB) of the Mirishkar 
district; II-point - meadow-alluvial soils (Fluvisols, WRB) of the Nishan district; III-point - takyr-meadow soils (Calsisols, WRB) of the Mubarek district; IV-point - gray-brown soils (Durisols Technic, WRB) of Termez district; V-point - irrigated takyr soils (Calsisols, WRB) of the Dzharkurgan district; VI-point - desert-sandy soils (Durisols Technic, WRB) of the Dzharkurgan district.

The physicochemical properties of soil samples were analysed by the following methods: soil $\mathrm{pH}$ according to the standard method (International Organization of Standardization 2005). Sampling and preparation of soils for analysis were carried out in accordance with GOST 17.4.4.02-84. The humus content according to Tjurin method 1970, the analysis of the water extract was carried out in accordance with GOST 26423-85. Organic carbon in the soil is determined and differentiated it by origin - natural (contained in unpolluted soil) and anthropogenic (introduced with organic pollutants). The formula for determining organic carbon of anthropogenic origin $\left(\mathrm{C}_{\mathrm{ant}}\right)$ has the following form:

$\mathrm{C}_{\text {ant }}=\mathrm{C}_{\text {org }}-\mathrm{C}_{\text {Control, }}[\%]$

where: $\mathrm{C}_{\text {Control, }}, \mathrm{C}_{\text {org }}-$ organic carbon, (method Okolelova et al. 2015) respectively, in unpolluted and contaminated soils.

Soil granulometric analysis were determined using the "Sieve" method (Tursunov 1988). The separation of the material into granulometric fractions is carried out using a standard set of sieves, followed by weighing the isolated fractions. For this reason, standard sieve sets with a size holes $10 ; 7 ; 5 ; 3 ; 1$; 0.5 ; and $0.25 \mathrm{~mm}$ with a saucer and lid. Chemical and physical characteristics of the collected samples which are the emergence of salinity due to pollution soil with oil and oil products were determined according to Arinushkina (1970). The determination of anthropogenic carbon quantity $-\mathrm{C}_{\text {ant }}$, the method of Okolelova (2015) was used.

Isolation oil-breakable bacteria's cultures from soil samples which were taken from different level of oil-contaminated areas in the research territory and their biochemical, physiological properties such as experiments carried out-acids creating from carbohydrates, modification relative to indol, nitro- gen reclamation, its property in the milk condition, activity relative to oxidase, catalase and nuclease, changing relative to lipase and pigments.

Isolated cultures are determined via observing activity of breaking between $0.5-20.0 \%$ concentrations of oil, prepared synthetic nutritional condition in $500 \mathrm{ml}$ roomy colba in $\left(\mathrm{g} / \mathrm{l}, \mathrm{KH}_{2} \mathrm{PO}_{4}-0.85\right.$, $\left(\mathrm{NH}_{4}\right) \mathrm{SO}_{4}-5.0, \mathrm{~K}_{2} \mathrm{HPO}_{4}-0.15, \mathrm{MgSO}_{4} \times 7 \mathrm{H}_{2} \mathrm{O}-0.5$, $\mathrm{NaCl}-0.1, \mathrm{CaCl}_{2} \times 4 \mathrm{H}_{2} \mathrm{O}-0.1$, distilled water $\times 1,000$ $\mathrm{ml}, \mathrm{pH} 6.0-7.8)$ The experiments were carried out in provided $28^{\circ} \mathrm{C}$ temperature condition during 3-57 and 30 days (Zvyaginsev 1991).

Field and laboratory experiments were mathematically and statistically based on the average arithmetic value of the experiments performed on 3-8 experiments $(n=3-8)$. The results are given in $\mathrm{M} \pm \mathrm{m}$, where $\mathrm{M}$ is the arithmetic mean and $\mathrm{m}$ is the default error value. Moreover, the statistical reliability values of the experimental results and the control group were calculated on the basis of Student t-scores and were evaluated statistically as $P<0.05$. The mathematical and statistical processing was based on Statgraphics Centurion XVII (2015), OriginPro 7.5 (OriginLab Corporation, USA) and OriginLab OriginPro v. 8.5 SR1 (EULA, Northampton, MA 01060-4401, USA) using special software packages.

\section{RESULTS}

The territory of the study area is irrigated, as it is a desert region, in fact, non-polluted soils. The $\mathrm{pH}$ is slightly alkaline (7.0-7.8). The results show that contamination with oil and petroleum products of the soil has decreased $\mathrm{pH}$ and chemical processes have changed in the soil (Table 1).

Soil $\mathrm{pH}$ shift is most common in gray-brown (Durisols Technic, WRB) and sandy dessert soils (Durisols Technic, WRB), which decreased from 7.3 to 5.2 and from 7.4 to 5.2 , respectively. These areas have the strongest pollution. Changes in soil conditions have a negative impact on the activity of microorganisms and plants living in the soil

According to the results, the $\mathrm{pH}$ in all studied samples are acidic relatively on the oil pollution level of soils. It may depend on soil chemical property and oil concentration in soil. When soil 
$\mathrm{pH}$ has the acidic condition, some reactions may go more intensive such as adsorption of heavy metals on soil organic matter could be easier, etc. Thus, it is necessary to have a neutral $\mathrm{pH}$ in the soils during the recultivation of oil pollution.

In addition, the oil and oil products are organic and sticky substance, which may effect to unite tiny aggregates $(0.25-0.5 \mathrm{~mm})$ in the soils. As a result, soil contamination by oil and petroleum total amount of essential importance for soil fertility $0.25 ; 0.5 ; 1$; $2 ; 3 ; 5 ; 7 ; 10 \mathrm{~mm}$ of the units underwent a drastic change. These changes analyzed, for example, alluvial meadow soil (Fluvisols, WRB) (Table 2).

The results show $0.25 \mathrm{~mm}$ units have compared with the control (5.07\%) with 5\% oil, gasoline and kerosene contamination have not changed, and at $15 \%$ contamination under the influence of oil has decreased to $0.01 \%$, motor oil to $0.035 \%$, kerosene to $0.094 \%$, and gasoline had no effect. Against the backdrop of $0.5 \mathrm{~mm}$ aggregates, the number of aggregates is $15.37 \%$, under the influence of oil, their quantity has decreased to $5.05 \%$, motor oil to $3.03 \%$, kerosene to $1.02 \%$. Due to a sharp decrease in the number of 0.25 and $0.5 \mathrm{~mm}$ aggregates, the number of 1-3 mm aggregates has increased sharply, in particular, the amount of $1 \mathrm{~mm}$ aggregates in the control is $19.14 \%$, under the influence of motor oil, their quantity has increased to $34.15 \%$ under the influence of kerosene to $33.56 \%$, the amount of $2 \mathrm{~mm}$ aggregates in the control is $11.52 \%$, under the in-

$\mathrm{T}$ a

The $\mathrm{pH}$ of oil polluted soils

\begin{tabular}{|c|c|c|c|c|c|c|}
\hline \multirow{2}{*}{$\mathrm{pH}$ indication } & \multicolumn{6}{|c|}{ Soil types } \\
\cline { 2 - 7 } & $\begin{array}{c}\text { Gray-brown } \\
\text { (Durisols } \\
\text { Technic, WRB) }\end{array}$ & $\begin{array}{c}\text { Irrigated } \\
\text { meadow-alluvial } \\
\text { (Fluvisols, } \\
\text { WRB) }\end{array}$ & $\begin{array}{c}\text { Irrigated grey- } \\
\text { brown } \\
\text { (Durisols, } \\
\text { WRB) }\end{array}$ & $\begin{array}{c}\text { Irrigated takyr- } \\
\text { meadow } \\
\text { (Calsisols, } \\
\text { WRB) }\end{array}$ & $\begin{array}{c}\text { Takyr } \\
\text { (Calsisols, } \\
\text { WRB) }\end{array}$ & $\begin{array}{c}\text { Sandy desert } \\
\text { (Durisols } \\
\text { Technic, WRB) }\end{array}$ \\
\hline Control & 7.3 & 7.6 & 7.8 & 7.0 & 7.2 & 7.4 \\
$\mathrm{pH}_{\mathrm{H} 2 \mathrm{O}}$ & 5.3 & 6.5 & 6.2 & 5.9 & 5.8 & 5.4 \\
$\mathrm{pH}_{\mathrm{KCI}}$ & 5.2 & 6.5 & 6.0 & 5.6 & 5.9 & 5.2 \\
\hline
\end{tabular}

$\mathrm{T}$ a $\mathrm{b} 1 \mathrm{e} \quad 2$

Influence of oil and oil products on the change soil aggregates [\%]

\begin{tabular}{|l|c|c|c|c|c|c|c|c|}
\hline \multirow{2}{*}{ Experiment options } & \multicolumn{9}{|c|}{ Soil aggregates } \\
\cline { 2 - 8 } & $10 \mathrm{~mm}$ & $7 \mathrm{~mm}$ & $5 \mathrm{~mm}$ & $3 \mathrm{~mm}$ & $2 \mathrm{~mm}$ & $1 \mathrm{~mm}$ & $0.5 \mathrm{~mm}$ & $0.25 \mathrm{~mm}$ \\
\hline Control & 8.80 & 8.70 & 18.60 & 12.80 & 11.52 & 19.14 & 15.37 & 5.07 \\
Oil [5\%] & 8.75 & 8.60 & 18.75 & 12.86 & 11.66 & 19.30 & 14.38 & 5.70 \\
Oil [15\%] & 13.00 & 13.76 & 13.63 & 22.00 & 17.36 & 15.19 & 5.05 & 0.01 \\
Engine oil [5\%] & 13.62 & 13.15 & 13.48 & 22.56 & 10.61 & 15.95 & 5.28 & 5.35 \\
Engine oil [15\%] & 17.02 & 13.40 & 13.06 & 20.29 & 17.44 & 15.45 & 3.31 & 0.035 \\
Petrol [5\%] & 8.39 & 8.70 & 18.60 & 12.16 & 11.50 & 19.70 & 15.48 & 5.47 \\
Petrol [15\%] & 8.65 & 8.73 & 17.45 & 12.70 & 11.09 & 19.97 & 15.71 & 5.70 \\
Kerosene [5\%] & 12.28 & 8.35 & 7.37 & 10.73 & 10.98 & 31.53 & 13.41 & 5.35 \\
Kerosene [15\%] & 14.82 & 11.97 & 11.18 & 14.38 & 12.97 & 33.56 & 1.12 & 0.094 \\
\hline
\end{tabular}


fluence of oil has increased to $17.36 \%$, motor oil is $20.44 \%$. The combination of aggregates in the soils is arranged in the following order of increase: gasoline - kerosene - engine oil - oil. This has led to a comprehensively complex process of agrophysical degradation. According to the results, in the processes of their pollution with oil and oil products, under the influence of salts rising together with oil-water, some soils undergo technogenic salinization (Table $3)$.

The existence of technogenic salinization of soils is depending on the chemical composition of the oil. For instance, gray-brown soils (Durisols Technic, WRB) are not salinated, medium salinity (chloride-sulphur type) existence due to influence of contamination with oil, irrigated meadow-alluvial (Fluvisols, WRB) soils are medium salinated in the control (sulfate-chloride type). The takyr-meadow soils (Calsisols, WRB) are not salinated in the control, they have not changed on the influence of contamination. Irrigated gray-brown soils (Durisols Technic, WRB) are not salinated in the control, medium salinated under the affect of contamination (chloride-sulphur type). Takyr soils (Calsisols,

$\mathrm{T}$ a $\mathrm{b} 1$ e 3

The emergence of salinity due to pollution soil with oil and oil products based on the method of E. V. Arinushkina)

\begin{tabular}{|c|c|c|c|c|c|}
\hline Soil type & $\begin{array}{c}\text { Depth } \\
{[\mathrm{cm}]}\end{array}$ & Dry residue & $\mathrm{HCO}_{3}^{-}$ & $\mathrm{Cl}^{-}$ & $\mathrm{SO}_{4}^{--}$ \\
\hline \multirow{2}{*}{ Control } & $0-35$ & $0.192 \pm 0.051$ & $0.051 \pm 0.0011$ & $0.012 \pm 0.003$ & $0.118 \pm 0.0022$ \\
\hline & $35-62$ & $0.110 \pm 0.033$ & $0.030 \pm 0.0012$ & $0.009 \pm 0.0002$ & $0.050 \pm 0.0012$ \\
\hline \multirow{2}{*}{$\begin{array}{c}\text { Gray-brown } \\
\text { (Durisols Technic, } \\
\text { WRB) }\end{array}$} & $0-35$ & $1.214 \pm 0.031$ & $0.049 \pm 0.0011$ & $0.950 \pm 0.21$ & $1.405 \pm 0.042$ \\
\hline & $35-62$ & $0.750 \pm 0.021$ & $0.031 \pm 0.0013$ & $0.420 \pm 0.011$ & $1.210 \pm 0.032$ \\
\hline \multirow{2}{*}{ Control } & $0-35$ & $1.310 \pm 0.022$ & $0.030 \pm 0.0014$ & $0.032 \pm 0.0004$ & $0.660 \pm 0.013$ \\
\hline & $35-62$ & $1.140 \pm 0.023$ & $0.024 \pm 0.0013$ & $0.030 \pm 0.0002$ & $0.640 \pm 0.012$ \\
\hline \multirow{2}{*}{$\begin{array}{l}\text { Irrigated meadow- } \\
\text { alluvial } \\
\text { (Fluvisols, WRB) }\end{array}$} & $0-35$ & $1.330 \pm 0.021$ & $0.035 \pm 0.0012$ & $0.045 \pm 0.0003$ & $0.681 \pm 0.012$ \\
\hline & $35-62$ & $1.180 \pm 0.032$ & $0.026 \pm 0.0011$ & $0.047 \pm 0.0004$ & $0.645 \pm 0.014$ \\
\hline \multirow{2}{*}{ Control } & $0-35$ & $0.810 \pm 0.023$ & $0.020 \pm 0.0010$ & $0.028 \pm 0.0002$ & $0.434 \pm 0.010$ \\
\hline & $35-62$ & $0.720 \pm 0.022$ & $0.020 \pm 0.0013$ & $0.022 \pm 0.0002$ & $0.412 \pm 0.012$ \\
\hline \multirow{2}{*}{$\begin{array}{c}\text { Irrigated grey- } \\
\text { brown } \\
\text { (Durisols, WRB) }\end{array}$} & $0-35$ & $1.722 \pm 0.032$ & $0.022 \pm 0.0010$ & $1.145 \pm 0.023$ & $1.035 \pm 0.044$ \\
\hline & $35-62$ & $0.920 \pm 0.020$ & $0.019 \pm 0.0012$ & $0.574 \pm 0.0005$ & $1.198 \pm 0.043$ \\
\hline \multirow{2}{*}{ Control } & $0-35$ & $0.650 \pm 0.025$ & $0.021 \pm 0.0014$ & $0.020 \pm 0.0003$ & $0.352 \pm 0.005$ \\
\hline & $35-62$ & $0.830 \pm 0.029$ & $0.020 \pm 0.0011$ & $0.032 \pm 0.0003$ & $0.322 \pm 0.003$ \\
\hline \multirow{2}{*}{$\begin{array}{c}\text { Irrigated takyr- } \\
\text { meadow } \\
\text { (Calsisols, WRB) }\end{array}$} & $0-35$ & $0.710 \pm 0.027$ & $0.025 \pm 0.0011$ & $0.022 \pm 0.0002$ & $0.374 \pm 0.007$ \\
\hline & $35-62$ & $0.887 \pm 0.026$ & $0.024 \pm 0.0012$ & $0.034 \pm 0.0002$ & $0.356 \pm 0.003$ \\
\hline \multirow{2}{*}{ Control } & $0-35$ & $0.230 \pm 0.014$ & $0.040 \pm 0.0013$ & $0.014 \pm 0.0003$ & $0.134 \pm 0.002$ \\
\hline & $35-62$ & $0.160 \pm 0.013$ & $0.030 \pm 0.0014$ & $0.012 \pm 0.0001$ & $0.062 \pm 0.001$ \\
\hline \multirow{2}{*}{$\begin{array}{c}\text { Takyr } \\
\text { (Calsisols, WRB) }\end{array}$} & $0-32$ & $0.239 \pm 0.010$ & $0.042 \pm 0.0013$ & $0.020 \pm 0.0001$ & $0.138 \pm 0.002$ \\
\hline & $32-60$ & $0.180 \pm 0.019$ & $0.035 \pm 0.0012$ & $0.018 \pm 0.0002$ & $0.070 \pm 0.002$ \\
\hline \multirow{2}{*}{ Control } & $0-35$ & $1.620 \pm 0.032$ & $0.021 \pm 0.0011$ & $0.036 \pm 0.0002$ & $1.070 \pm 0.041$ \\
\hline & $35-62$ & $1.340 \pm 0.031$ & $0.020 \pm 0.0014$ & $0.030 \pm 0.0003$ & $0.900 \pm 0.021$ \\
\hline \multirow{2}{*}{$\begin{array}{c}\text { Sandy desert } \\
\text { (Durisols Technic, } \\
\text { WRB) }\end{array}$} & $0-35$ & $1.768 \pm 0.038$ & $0.023 \pm 0.0013$ & $0.037 \pm 0.0002$ & $1.097 \pm 0.040$ \\
\hline & $35-62$ & $1.471 \pm 0.035$ & $0.024 \pm 0.0010$ & $0.040 \pm 0.0002$ & $0.968 \pm 0.022$ \\
\hline
\end{tabular}


WRB) are not salinated in the control, they have not changed on the influence of contamination. Desert sandy soils (Durisols Technic, WRB) are medium salinated in the control (chloride-sulfate type), they also have not changed on the influence of pollution.

From the given data, it can be seen that man-made pollution resulting from oil pollution occurs only in soils belonging to the sections and in the remaining soils, salinization has not occurred. This reason is explained by the amount of chloride and sulfate salts emitted together with oil from oil mines.

As a result of soil pollution with oil and oil products, the amount of carbon has increased sharply. In all studied soils, pollution has affected the increase in the amount of carbon, however, a sharp increase in the amount of carbon in a short time has not affected the increase in the amount of humus, since carbon, which increases in a short time, is considered anthropogenic carbon $\left(\mathrm{C}_{\text {ant }}\right)$ (Figure 1).

The results show that oil pollution had an effect on the increase in the amount of total carbon $\left(\mathrm{C}_{\text {total }}\right)$, in particular in the horizons $0-35 \mathrm{~cm}, 35-62 \mathrm{~cm}$, respectively, in the section grey-brown soil, increased by $0.22 \% ; 0.18 \%$; in the section of irrigated meadow-alluvial soil (Flusols, WRB) is $0.31 \%$;
$0.14 \%$; in the section sandy desert soil (Durisols Technic, WRB) is $0.44 \%$; $0.34 \%$; in the section irrigated takyr-meadow soil (Calsisols, WRB) is $0.25 \% ; 0.14 \%$; in the section of takyr soil (Calsisols, WRB) is $0.32 \% ; 0.27 \%$; in the section of irrigated gray-brown soil (Durisols Technic, WRB) has increased to $0.21 \% ; 0.14 \%$. In the horizon $62-85 \mathrm{~cm}$ lower in all sections with no increase in the amount of carbon. In the laboratory, the concentrations of oil and petroleum products (gasoline, kerosene, engine oil) $0.5-35 \%$ for 30 days an increase in carbon is noted, which proves this position. The increase in the amount of carbon only in the upper horizons is explained by the fact that oil and oil products contamination occurs only in the upper horizons of the soil profile. The correlation between anthropogenic carbon of $\mathrm{C}_{\text {ant }}$ and humus is $r=-0.92$, therefore, the increase in the number of $\mathrm{C}_{\text {total }}$ due to $\mathrm{C}_{\text {ant }}$ resulted in pollution which does not increase the amount of humus and this is considered not essential for soils.

The heterogeneity in pollution character and lack of any regular occurrence might be explained on two bases. The first basis is the difference of soil-climatic conditions, soil-forming rocks and oil chemical contents that "Kukdumalok" and "Khovdak" oil

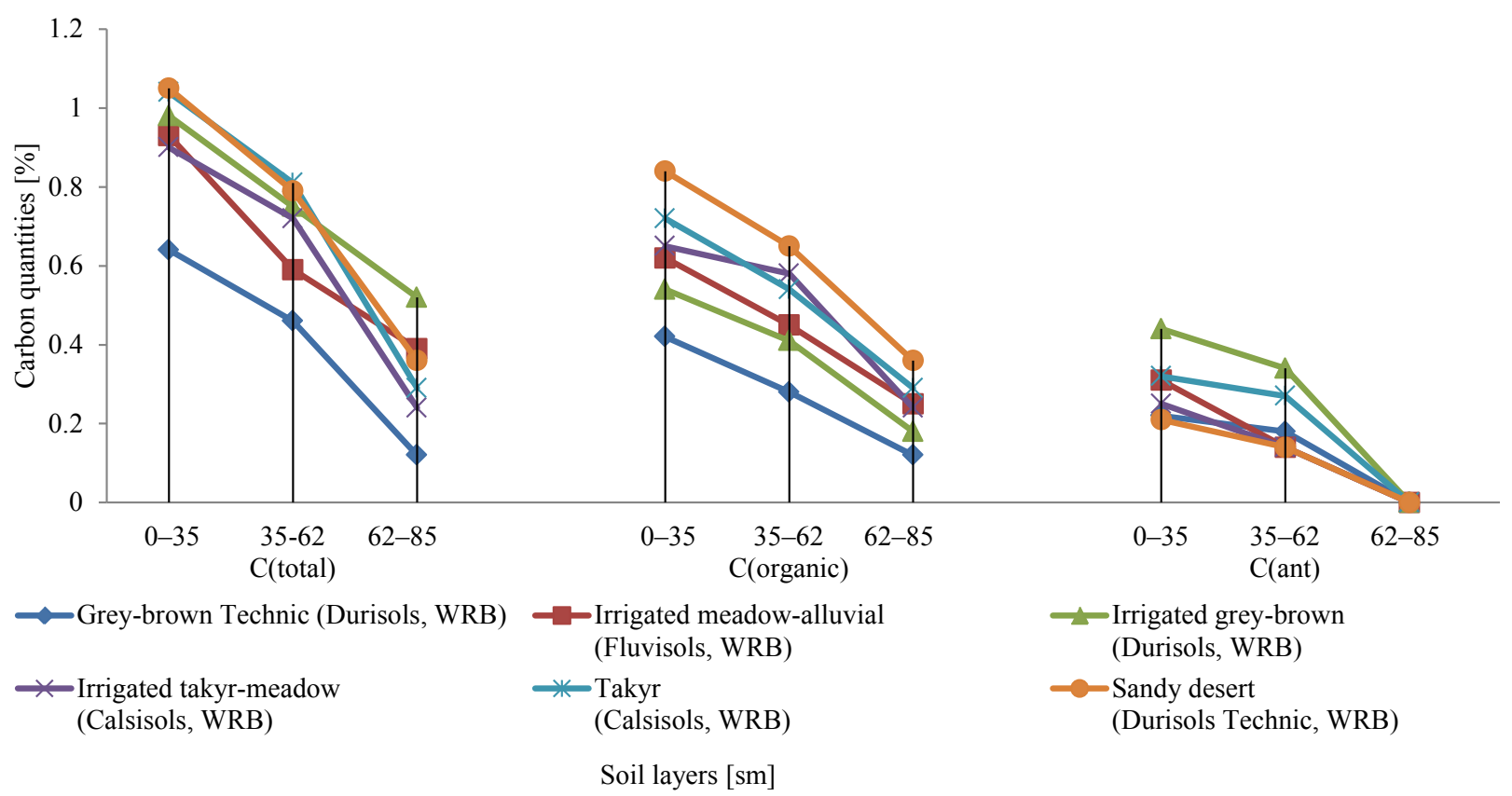

Figure 1. Change in the amount of carbon due to pollution soil with oil and oil products 
fields are situated in separate areas. The second basis might be seen in technological perfectness and working efficiency of the oil fields that could cause an environmental contamination in surrounding areas.

The concentrations of analysed elements are higher in the samples taken from sandy soils (Durisols Technic, WRB) than the samples of gray-brown soils (Durisols Technic, WRB). Because there was an accident in the oil pipeline system 48 years ago causing pollution in the territory. Furthermore, any of recultivation measures have not been carried out in these territories. The scenario is little more different in the territory of "Kukdumalok", due to that the pollution was not so serious because of the technological efficiency of the oil field during the past period.

The microbiological community of soil affected under oil pollution that some amounts of microorganisms and physiological groups dead. Then plant cover are dramatically decreased and the biomass less accumulated.

The bioremediation of hydrocarbon degradation in petroleum-polluted soil is carried out by various microorganisms (Wu et al. 2017). Phytoremediation is an actively developing biotechnology that uses plants, their associated microorganisms, and agricultural techniques for the rehabilitation of environments contaminated by inorganic and organic pollutants (Panchenko et al. 2017). The degradation of total petroleum hydrocarbons in soils and several physiological parameters of plants such as shoot length and biomass were analyzed (Kuo et al. 2014). Bioremediation using microorganisms and plants are a promising method for the degradation of crude oil contaminants (Gao et al. 2014). Bioremediation is the most effective way to remove these pollutants in the soil (Mohammadi-Sichani et al. 2017). Moreover, the bioremediation has been widely applied to decontaminate petroleum-contaminated sites ( $\mathrm{Li}$ et al. 2016). The dynamics of the decrease of oil product content and the time of elimination of the toxic effects on higher plants at the initial pollutant contents were revealed (Petrov et al. 2016).

Joint use of strains is more effective than their separate use. In particular, at oil concentrations of $5 \%, 12 \%, 23 \%, 37 \%$ for 45 days, the maximum amount of the strain of MFD-100 Pseudomonas stutzeri was determined according to the titer of $3.7 \times 10^{7}$; $4.1 \times 10^{7} ; 4.5 \times 10^{7} ; 4.6 \times 10^{7} \mathrm{cells} / \mathrm{ml}$; strain MFD200 Pseudomonas caryophylli $-3.2 \times 10^{7} ; 3.5 \times 10^{7}$; $3.7 \times 10^{7} ; 3.9 \times 10^{7} ;$ strain MFD-5000 Bacillus subtilis $-3.6 \times 10^{8} ; 3.7 \times 10^{8} ; 3.8 \times 10^{8} ; 3.9 \times 10^{8}$; and in the consortium $-7.2 \times 10^{9} ; 7.6 \times 10^{9} ; 7.8 \times 10^{9} ; 7.9 \times 10^{9}$ cells $/ \mathrm{ml}$. From this point of view, the use of strains in the consortium produces high results. Also, Sorghum saccharatum, Medicago falcata L., Artemisia diffusa H. Krasch, Anabasis eriopoda (Schrenk) Benth are used as phytoremediation to improve contaminated soil biodegradation and reclamation results were incredible.

In general, the individual recultivation factors are considered taking into account the soil and climatic conditions of the desert zone of Kashkadarya and Surkhandarya: the nature of the pollution (timing, level, type of pollution), the climatic factor (high temperature, low precipitation), the chemical composition and soil properties, biological and microbiological soil parameters.

$\mathrm{T}$ a b 1 e 4

Separation for periods of recultivation of oil-contaminated and oil products of desert soils according to the norms of minimum and maximum time, in months

\begin{tabular}{|l|c|c|c|c|}
\hline \multirow{2}{*}{ Periods } & \multicolumn{4}{c|}{ Degree of pollution } \\
\cline { 2 - 5 } & Slightly & Medium & High & Very high \\
\hline Preparation period for reclamation & $1-2$ & $1-2$ & $1-2$ & $1-2$ \\
The period of reclamation (bioremediation) & $10-14$ & $16-22$ & $24-34$ & $37-46$ \\
The period of preliminary restoration of soil fertility & $4-6$ & $8-10$ & $10-12$ & $12-16$ \\
The total period & $15-22$ & $25-34$ & $35-48$ & $50-64$ \\
\hline
\end{tabular}


The technology of reclamation is created taking into account the requirements of the Interstate Standard GOST.17.5.1.01.-83, foreign experience and the soil and climatic conditions of the research facility. This technology of reclamation based on the biological method consists of a complex of 11 measures of 6 species based on 3 stages, 3 periods, its terms are divided into periods by the degree of contamination (Table 4).

The reclamation time of the soils of the desert zone is different, according to general analysis, depending on the degree of contamination, it is $15-64$ months, of which the most time (72\%) falls on the period of remediation. The expenditure of time in the restoration of soil fertility refers to the initial state, with time it is equal to the soils of the control territories.

The degree of purification of the investigated soils is different, according to these data, the degree of purification of desert sandy soils (Durisols Technic, WRB) is $92.87 \%$. Irrigated takyr-meadow soils (Calsisols, WRB) is $74.19 \%$. Gray-brown soils (Durisols Technic, WRB) is $74.75 \%$. Irrigated meadow-alluvial soils (Fluvisols, WRB) is $93.12 \%$. Takyr soils (Calsisols, WRB) is $82.91 \%$ and in irrigated gray-brown soils (Durisols Technic, WRB) is $94.4 \%$.

\section{DISCUSSION}

Soil contamination by engine oil causes huge damage to the environment (Solly et al. 2015). The change in soil $\mathrm{pH}$ depends on the fractional composition of oil and petroleum products falling into the soil. The experiments have revealed that the soil condition improves after recultivation. The concentration of the pollutant depends on the chemical composition of the soil. Most microbial species can survive only within a certain $\mathrm{pH}$ range. Furthermore, soil $\mathrm{pH}$ can affect the availability of nutrients (Agamuthu et al. 2013). Depending on pollutants, the soil $\mathrm{pH}$ can be increased to neutral (6.6-7.3).

Oil and oil products (gasoline, engine oil, kerosene) have affected soil aggregates. Although, the $\mathrm{PAH}$ contamination in the different granulometric fractions is directly proportional to the respective total organic carbon content since the PAH is asso- ciated with the carbonaceous particulate materials (Trellu et al. 2017). Since the pollutants are organic matter, the aggregate of $0.25-3.00 \mathrm{~mm}$ have been intensified and sharply reduced. As a result, 7-10 $\mathrm{mm}$ aggregate have increased. In soil, the concentration of kerosene $15 \%, 0.25 \mathrm{~mm}$ of aggregate decreased to $98 \%$. Changes in soil aggregate adversely affect the transfer and storage of water. In addition, the negative effects on air and nutrient regimens. The change of soil aggregate is temporary, and after recultivation, it returns to its original state.

The salinity of the soil has evolved around some oilfields. Its appearance is related to the chemical composition of the water from the oilfield. Graybrown (Durisols Technic, WRB), irrigated meadow-alluvial (Fluvisols, WRB), irrigated gray-brown (Durisols Technic, WRB), irrigated grey-brownmeadow (Durisols, WRB), sandy dessert soils (Durisols Technic, WRB) are slightly and moderately saline. Takyr soils (Calsisols, WRB) are non-saline soils. The sulfate ions ( $\left.\mathrm{SO}^{--}\right)$in the salinity reached a maximum of $1.4045 \%$, and chlorine ions $\left(\mathrm{Cl}^{-}\right)-1.145 \mathrm{mg} / \mathrm{kg}$. Such anthropogenic salinity is not found in large areas. They only occur around the oil field. It is not a major issue for the agrarian sector.

It can be proved the decreasing of humus content in desert soil polluted with oil and oil products. Firstly, the physical properties of soil such as density increasing and moisture decreasing under oil pollution can lead to the humification process ongoing in the soil breaks down. Secondly, if amounts of chemical substances in soil (such as oil and oil products, heavy metals, salts, etc.) reach the maximum allowable concentrations can cause damage of whole processes in soil. Thirdly, plant cover richness is decreased, in some areas totally destroys and in its turn the biomass incoming back to soil decreases sharply, but oat could increase the microbial respiration rate and improve hydrocarbon degradation in the soil in all the TPH-contaminated treatments (Barati et al. 2018). Moreover, applying wheat straw as biostimulator may mitigate the negative impacts of the contamination with crude oil on soil organic carbon mineralization and crude oil degradation (Hamoud et al. 2018). After phytoremediation, the soil can be used as the agricultural soil (Smaranda et al. 2016). Fourthly, the microorganisms' amount 
and their physiological groups can decrease and if pollution is high in level they can negatively impacted. In all studied soils, respectively, the degree of pollution with oil and petroleum products increased the amount of carbon. This carbon is considered as anthropogenic carbon $(\mathrm{C})$, which does not have a correlation with humus of soils. Therefore, it is not effective in soil fertility.

Application of strain of MFD-100 Pseudomonas stutzeri, strain MFD-200 Pseudomonas caryophyllis, strain MFD-5000 Bacillus subtilis, and Sorghum saccharatum, Medicago falcata L., Artemisia diffusa H. Krasch, Anabasis eriopoda (Schrenk) Benth to reclamation have effected to clean-up and have improved soil conductivity. Both biostimulation and bioaugmentation have a positive influence on the biological activity of soil and its physicochemical properties (Polyak et al. 2018). All the soils need separated time. It should be separated by levels of pollution. Because it is related to the economic cost. In the desert region, this figure was at least 15 months (slight pollution) and maximum (very high pollution) 64 months.

After the pollution of soils, the amount of oil under the effect of photochemical, chemical, physical and biological processes in soil has been degraded and decreased. In these soils, the heavy fractions of oil like pitch, asphalt kept collapsed the soil processes. Providing of recultivation measures in these soils may create difficulties than short-term polluted soils.

\section{CONCLUSIONS}

The change in soil $\mathrm{pH}$ is harmful to soil properties and productivity. It is necessary to bring oil to the recultivation. Carbon dioxide is unnecessary in contamination, so it is recommended to use organic fertilisers in recultivation. A significant effect of the concentration of oil and oil products $(5-15 \%)$ on the number of soil aggregates studied $(0.25,0.5,1$, $2,3,5,7,10 \mathrm{~mm})$, in particular, a decrease in the amount of $0.25 \mathrm{~mm}$ aggregates and an increase in the number of $2-3 \mathrm{~mm}$ aggregates.

Technogenic salinity with soil pollution with oil and oil products do not cover large areas and damage to agriculture is not high. Using MFD-100 Pseudo- monas stutzeri, MFD-200 Pseudomonas caryophylli, MFD-5000 Bacillus subtilis bacterial strains of $8.2 \times 1011$ cells / $1 \mathrm{~g}$ to remove oil and oil products from the desert zone in irrigated soils and planting Sorghum saccharatum, Medicago falcata L., Artemisia diffusa H. Krasch, Anabasis eriopoda (Schrenk) Benth have given high efficiency. After the recultivation, soil fertility has restored and the properties have improved over time. The effect of the remediation activities has greatly improved the properties of contaminated soils.

\section{REFERENCES}

AGAMUTHU, P. - TAN, Y.S. - FAUZIAH, S.H. 2013. Bioremediation of hydrocarbon contaminated soil using selected organic wastes. In Procedia Environmental Sciences, vol. 18, pp. 694-702. DOI: org/10.1016/j. proenv.2013.04.094

AGNELLO, A.C. - BAGARD, M. - HULLEBUSCH, E.D. - ESPOSITO, G. - HUGUENOT, D. 2016. Comparative bioremediation of heavy metals and petroleum hydrocarbons co-contaminated soil by natural attenuation, phytoremediation, bioaugmentation and bioaugmentation-assisted phytoremediation. In Science of the Total Environment, vol. 563-564, pp. 693-703. DOI: org/10.1016/j.scitotenv.2015.10.061

AKINWUMI, I.I. - DIWA, D. - OBIANIGWE, N. 2014. Effects of crude oil contamination on the index properties, strength and permeability of lateritic clay. In Journal of Applied Sciences and Engineering Research, vol. 3, no. 4, pp. 816-824. DOI: 10.6088/ijaser.030400007

AKPOVETA, O.V. 2016. Fenton oxidative mechanism and its kinetics on the remediation of soil contaminated with unrefined petroleum oil. In Journal of Chemical Society of Nigeria, vol. 41 , no. 2 , pp. 54-61.

ALOTAIBI, H.S. - USMAN, A.R. - ABDULJABBAR, A.S. - OK, Y.S. - Al-FARAJ, A.I. - SALLAM, A.S. - AL-WABEL, M.I. 2018. Carbon mineralization and biochemical effects of short-term wheat straw in crude oil contaminated sandy soil. In Applied Geochemistry, vol. 88, pp. 276-287. DOI: org/10.1016/j.apgeochem.2017.02.017

ARINUSHKINA, E.V. 1970. Soil Chemical Analysis Guide. Moskow: Moscow State University Press, 488 pp.

BALLIANA, A.G. - MOURA, B.B. - INCKOT, R.C. - BONA, C. 2017. Development of Canavalia ensiformis in soil contaminated with diesel oil. In Environmental Science and Pollution Research International, vol. 24, no. 1, pp. 979-986. DOI: $10.1007 / \mathrm{s} 11356-016-7674-1$

BARATI, M. - SAFARZADEH, S. - MOWLA, D. - BAKHTIARI, F. 2018. Improvement of petroleum hydrocarbon remediation using the oat plant in the soil treated by poultry manure. In Journal of Advances in Environmental Health Research, vol. 6, no. 4, pp. 253-261. DOI: 10.22102/ JAEHR.2018.141039.1094

CRUZ, J.M. - LOPES, P.M. - MONTAGNOLLI, N. - TAMADA, I.S. - GSILVA, N.M. -BIDOIA, E.D. 2013. Phytotoxicity of soil contaminated with petroleum derivatives and biodiesel. In Ecotoxicology and Environmental Contamination, vol. 8, no. 1, pp. 49-54. DOI: 10.5132/eec.2013.01.007 
ERRINGTON, I - KING, C.K. - HOULAHAN, S. - GEORGE, S.C. - MICHIE, A. - HOSE, G.C. 2018. The influence of vegetation and soil properties on springtail communities in a diesel-contaminated soil. In Science of the Total Environment, vol. 1, pp. 1098-1104. DOI: org/10.1016/j. scitotenv.2017.11.186

FAO. 2014. World reference base for soil resources, http://www. fao.org

GAO, Y. - GUO, SH. - WANG, J. - LI, D. - WANG, H. - ZENG, D. 2014. Effects of different remediation treatments on crude oil contaminated saline soil. In Chemosphere, vol. 117, pp. 486-493. DOI: 10.1016/j.chemosphere.2014.08.070

GARGOURI, B. - KARRAY, F. - ZHIRI, N. - ALOUI, F. SAYADI, S. 2014. Bioremediation of petroleum hydrocarbons-contaminated soil by bacterial consortium isolated from an industrial wastewater treatment plant. In Journal of Chemical Technology and Biotechnology, vol. 89, pp. 978-987. DOI: $10.1002 /$ jctb.4188

GOST. 17.4.4.02-84. 2008. Nature protection. Soils. Methods for sampling and preparation of soil for chemical, bacteriological and helmintoglogical analysis. pp. $1-8$.

GUARINO, C. - SPADA, V. - SCIARRILLO, R. 2017. Assessment of three approaches of bioremediation (Natural Attenuation, Landfarming and Bioagumentation e Assistited Landfarming) for a petroleum hydrocarbons contaminated soil In Chemosphere, vol. 170, pp. 10-16. DOI: org/10.1016/j. chemosphere.2016.11.165

HUANG, L. - XIE, J. - BY, L.V. - SHI, X.F. - LI, G.Q. - LIANG, F.L. - LIAN, J. 2013. Optimization of nutrient component for diesel oil degradation by Acinetobacter beijerinckii ZRS. In Marine Pollution Bulletin, vol. 76, no. 1-2, pp. 325-332. DOI: 10.1016/j.marpolbul.2013.03.037

International standard. 2005. International Organization of Standardization. Standard of Soil quality, ISO, 10390:2005 (E).

IQBAL, M.Z. - KHURSHEED, S. - SHAFIQ, M. 2016. Effects of motor oil pollution on soil and seedling growth of Parkinsonia aculeata L. In Scientia Agriculturae, vol. 13, no. 3 , pp. 130-136. DOI: 10.15192/PSCP.SA.2016.13.3.130136

KARPOV, A.V. 2013. Development of technology for ecological remediation of man-caused lands by the example of the impact zone of the Volgograd Refinery. PhD dissertation. Volgograd: Volgograd State University.

KÄSTNER, M. - MILTNER, A. 2016. Application of compost for effective bioremediation of organic contaminants and pollutants in soil. In Applied Microbiology and Biotechnology, vol. 100, pp. $3433-3443$. DOI: $10.1007 / \mathrm{s} 00253-016-$ 7378-y

KUO, H.C. - JUANG, D.F. - YANG, L. - KUO, W.C. - WU, Y.M. 2014. Phytoremediation of soil contaminated by heavy oil with plants colonized by mycorrhizal fungi. In International Journal of Environmental Science and Technology, vol. 11 , no. 6 , pp. $1661-1668$. DOI: 10.1007/s13762-0130353-6

LAWSON, I.YD. - NARTEY, E.K. - DARKO, D.A. - OKRAH, V.A. - TSATSU, D. 2012. Microbial degradation potential of some Ghanaian soils contaminated with diesel oil. In $A g$ riculture and Biology Journal of North America, vol. 3, no. 1, pp. 1-5. DOI: 10.5251/abjna.2012.3.1.1.5

LI, J. - GUO, C. - LU, G. - YI, X. - DANG, Z. 2016. Bioremediation of petroleum - contaminated acid soil by a constructed bacterial consortium immobilized on sawdust: influences of multiple factors. In Water, Air, \& Soil Pollution, vol. 227 , no. 12 , pp. $444-452$. DOI: org/10.1007/s11270-0163117-3

LIM, M.W. - LAU, E.V. - POH, P.E. 2016. A comprehensive guide of remediation technologies for oil contaminated soil - Present works and future directions. In Marine Pollution
Bulletin, vol. 109, no. 1, pp. 14-45. DOI: org/10.1016/j. marpolbul.2016.04.023

MOHAMMADI-SICHANI, M.M. - ASSADI, M.M. - FARAZMAND, A. - KIANIRAD, M.A. - AHADI, M. - GHAHDERIJANI, H.H. 2017. Bioremediation of soil contaminated crude oil by Agaricomycetes. In Journal of Environmental Health Science \& Engineering, vol. 15, no. 8, pp.1-6. DOI.org/10.1186/s40201-016-0263-x

MOUBASHER, H.A. - HEGAZY, A.K. - MOHAMED, N.H. MOUSTAFA, Y.M. - KABIEL, H.F. - HAMAD A.A. 2015. Phytoremediation of soils polluted with crude petroleum oil using Bassia scoparia and its associated rhizosphere microorganisms. In International Biodeterioration \& Biodegradation, vol. 98, no. 3, pp. 113-120. DOI:10.1016/j. ibiod.2014.11.019

OKOLELOVA, A.A. - JELTOBRYUXOV, V.F. - TARACOB, A.P. - KASTERINA, N.G. 2015. Normal feature of oil products in the soil covering. In Scientific Magazine Fundamental Investigatin, vol. 23, no. 12, pp. 315-319.

PANCHENKO, L. - MURATOVA, A. - DUBROVSKAYA, E. - GOLUBEV S. -TURKOVSKAYA, O. 2017a. Dynamics of natural revegetation of hydrocarbon-contaminated soil and remediation potential of indigenous plant species in the steppe zone of the southern Volga Uplands. In Environmental Science and Pollution Research, vol. 25, no. 4, pp. 3260-3274. DOI: org/10.1007/s11356-017-0710-y

PANCHENKO, L. - MURATOVA, A. - TURKOVSKAYA, O. 2017b. Comparison of the phytoremediation potentials of Medicago falcata $L$. and Medicago sativa $L$. in aged oil-sludge-contaminated soil. In Environmental Science and Pollution Research, vol. 24, no. 3, pp. 3117-3130. DOI: org/10.1007/s11356-016-8025-y

PETROV, A.M. - VERSIONING, A.A. - KARIMULLIN, L.K. - AKAIKIN, D.V. -TARASOV, O.YU. 2016. Dynamics of ecological and biological characteristics of soddy-podzolic soils under long-term oil pollution. In Eurasian Soil Science, vol. 49, no. 7, pp. 784-791. DOI: org/10.1134/ S1064229316050124

PETROVA, N.A. 2014. Influence of chemical pollution on biological properties of soils of dry steppes and semi-deserts of the south of Russia. PhD dissertation. Rostov-on-Don: Southern Federal University.

POLYAK, Y.M. - BAKINA, L.G. - CHUGUNOVA, M.V. MAYACHKINA, N.V. - GERASIMOV A.O. - BURE, V.M. 2018. Effect of remediation strategies on biological activity of oil-contaminated soil - A field study. In International Biodeterioration \& Biodegradation, vol. 126, no. 1, pp. 57-68. http://dx.doi.org/10.1016/j.ibiod.2017.10.004 ROY, A.S. - BARUAH, R. - BORAH, M. - SINGH, A.K. DEKA BORUAH, H.P. - SAIKIA, N. - DEKA, M. - DUTTA N. - BORA, T.CH. 2014. Bioremediation potential of native hydrocarbon degrading bacterial strains in crude oil contaminated soil under microcosm study. In International Biodeterioration \& Biodegradation, vol. 94, pp. 79-89. DOI: org/10.1016/j.ibiod.2014.03.024

SMARANDA, M. - EUGENIA, G. - IONICA, O. - MARIUS, P. 2016. For a sustainable development: Phytoremediation of oil-polluted soils by using birdsfoot trefoil crops. In Romanian Biotechnological Letter, vol. 22, no. 6, pp. $12010-12017$.

SOLEIMANI, M. - FARHOUDI, M. - JAN, H. 2013. Chemometric assessment of enhanced bioremediation of oil contaminated soils. In Journal of Hazardous Materials, vol. $254-255$, no. 15 , pp. $372-381$. DOI: $10.1016 /$ j. jhazmat.2013.03.004

SOLLY, G. - ASWATHY, E. - BERLIN, S. - KRISHNAPRABHA, N. - MARIA, G. 2015. Study on geotechnical 
properties of diesel oil contaminated soil. In International Journal of Civil and Structural Engineering Research, vol. 2, no. 2, pp. 113-117.

TRELLU, C. - MILTNER, A. - GALLO, R. - HUGUENOT, D. - HULLEBUSCH E.D. - ESPOSITO, G. - OTURAN, M.A. - KÄSTNER, M. 2017. Characteristics of PAH tar oil contaminated soils-Black particles, resins and implications for treatment strategies. In Journal of Hazardous Materials, vol. 327, pp. 206-215. DOI: org/10.1016/j. jhazmat.2016.12.062

TUMANYAN, A.F. - TYUTYUMA, N.V. - BONDARENKO, A.N. - SHCHERBAKOVA, N.A. 2017. Influence of oil pollution on various types of soil. In Chemistry and Technology of Fuels and Oils, vol. 53, no. 3, pp. 369-376. DOI: 10.1007/s10553-017-0813-7

TURSUNOV, L. 1988. Soil physics. Tashkent: National University Press, 220 pp. ISBN 5-8244-0072-5

WANG, Y. - JIANG, F. - QIANXIN, L. - LYU, X. - WANG, X. - WANG, G. 2013. Effects of crude oil contamination on soil physical and chemical properties in Momoge wetland of China. In Chinese Geographical Science, vol. 23, no. 6, pp. 708 -715. DOI: 10.1007/s11769-013-0641-6
World reference base for soil resources, WRB, 2014 International soil classification system for naming soils and creating legends for soil maps. World Soil Resources reports. no. 106, Rome : FAO, $181 \mathrm{pp}$.

WU, M. - LI, W. - WARREN, A.D. - YE, X. - CHEN, K. - KOST, D. - CHEN, L. 2017. Bioremediation of hydrocarbon degradation in a petroleum contaminated soil and microbial population and activity determination. In Chemosphere, vol. 169, no. 18, pp. 124-130. DOI: 10.1016/j.chemosphere.2016.11.059.

ZVYAGINSEV, D.G. 1991. Methods of microbiology and biochemistry. Moscow: Moscow State University Press, 239 pp. ISBN 5-211-01675-0.

Received: January 10, 2019

Accepted: June 5, 2019 